\title{
A RATIONALE FOR THE USE OF ANTHROPOMETRIC MEASUREMENTS AND BIOELECTRICAL IMPEDANCE ANALYSIS AS EFFICACY CRITERIA FOR SUMMER CAMP HEALTHCARE
}

Gavryushin MYu $\bowtie$, Sazonova OV, Gorbachev DO, Borodina LM, Frolova OV, Tupikova DS

Samara State Medical University, Samara, Russia

\begin{abstract}
The proportion of obese and overweight children is alarmingly high. This dictates the need for promoting healthy lifestyle and eating habits in children. Summer camps provide a wide range of activities to improve children's health. However, methods used to assess children's nutritional status during a camp session need to be analyzed in depth, and a rationale should be provided for the use of bioelectrical impedance analysis (BIA) and anthropometric measurements as efficacy criteria for summer camp healthcare. We examined 125 boys and 221 girls aged 8-15 years spending their summer holidays at 3 different camps. Measurements were taken twice: on days 1 and 2 upon arrival to a camp and 2 days before leaving for home. In each camp, both positive and negative health weight dynamics were observed. The overall weight dynamics in children from camps 1 and 2 were statistically insignificant $(p=0.415$ and $p=0.585$ ), in contrast to camp 3 where those changes were significant $(p=0.025)$. BIA revealed that less than $44.34 \%$ of children had gained skeletal muscle mass during their stay at the camp, whereas weight loss was associated with both decreased fat and skeletal muscle masses. BIA confirms the results of anthropometric measurements and also provides information about the diet offered to children and their level of physical activity. Therefore, the use of anthropometric measurements and BIA could be an informative method for assessing the efficacy of healthcare in summer camps.
\end{abstract}

Keywords: hygiene of children and adolescents, physical development, anthropometry, bioimpedance analysis, nutritional status, diet

Author contribution: Gavryushin MYu — study design, data acquisition and analysis, interpretation of the results; Sazonova OV — study design, interpretation of the results; Gorbachev DO — literature analysis, manuscript draft; Borodina LM — data analysis, interpretation of the results; Frolova OV — manuscript revision, literature analysis; Tupikova DS — manuscript draft.

Compliance with ethical standards: this study was approved by the Ethics Committee of Samara State Medical University (Protocol No. 8 dated September 13, 2018). Informed consent was obtained from all the participants or their legal representatives.

Correspondence should be addressed: Mikhail Yu. Gavryushin

Chapaevskaya 87, Samara, 443099; m.yu.samara@mail.ru

Received: 10.12.2018 Accepted: 29.03.2018 Published online: 12.04.2019

DOI: 10.24075/brsmu.2019.024

\section{НАУЧНОЕ ОБОСНОВАНИЕ ПРИМЕНЕНИЯ РЕЗУЛЬТАТОВ АНТРОПОМЕТРИЧЕСКИХ ИССЛЕДОВАНИЙ И БИОИМПЕДАНСНОГО АНАЛИЗА В КАЧЕСТВЕ КРИТЕРИЕВ ОЦЕНКИ ЭФФЕКТИВНОСТИ ОЗДОРОВЛЕНИЯ ДЕТЕЙ В ЛЕТНИХ ЛАГЕРЯХ}

М. Ю. Гаврюшин, О. В. Сазонова, Д. О. Горбачев, Л. М. Бородина, О. В. Фролова, Д. С. Тупикова

Самарский государственный медицинский университет, Самара, Россия

В современных условиях жизни высока доля детей с избыточной массой тела и ожирением. Очевидна необходимость оздоровления детей, способствующего коррекции пищевого статуса. На выполнение этой задачи направлена работа детских организаций отдыха и оздоровления, в том числе летних лагерей. Необходимы анализ различных методов оценки изменений пищевого статуса детей в течение лагерной смены и научное обоснование возможности применения результатов биоимпедансного анализа состава тела (БИА) и антропометрических измерений в качестве критериев оценки эффективности оздоровления детей в лагерях. Обследованы 125 мальчиков и 221 девочка в возрасте 8-15 лет, отдыхающие в трех детских лагерях. Исследования проводили в 2 этапа: на 1-й, 2-й дни заезда и за 2 дня до окончания лагерной смены. В каждой организации выявлены дети, у которых за период лагерной смены отмечена как положительная, так и отрицательная тенденция изменения массы тела. Общая тенденция к изменению массы тела среди детей в лагерях № 1 и № 2 была статистически незначима ( $p=0,415$ и p = 0,585), а в лагере № 3 отмечена достоверная тенденция к изменению массы тела отдыхающих ( $p=0,025)$. По данным БИА, повышение массы тела в течение лагерной смены не более чем в 44,34\% случаев сопровождалось должным повышением скелетно-мышечной составляющей, а снижение массы тела включало потерю как жировой, так и скелетно-мышечной составляющих. БИА не только дополняет результаты антропометрических исследований, но и позволяет сделать предположение о фактическом питании и уровне двигательной активности детей. Соответственно, применение антропометрических исследований в совокупности с данными БИА может служить в качестве инфформативного методического подхода к оценке эффективности оздоровления детей в летних лагерях.

Ключевые слова: гигиена детей и подростков, физическое развитие, антропометрия, биоимпедансный анализ, пищевой статус, рацион питания

Информация о вкладе авторов: М. Ю. Гаврюшин — планирование исследования, сбор данных, анализ данных, интерпретация результатов; О. В. Сазонова планирование исследования, интерпретация результатов; Д. О. Горбачев - анализ литературы, подготовка черновика рукописи; Л. М. Бородина - анализ данных, интерпретация результатов; О. В. Фролова - редактирование статьи, анализ литературы; Д. С. Тупикова - подготовка черновика рукописи.

Соблюдение этических стандартов: исследование одобрено экспертной комиссией ФГБОУ ВО СамГМУ Минздрава России (протокол № 8 от 13 сентября 2018 г.). Все участники исследования (или их законные представители) подписали информированное согласие на участие в исследовании.

$\triangle$ Для корреспонденции: Михаил Юрьевич Гаврюшин

ул. Чапаевская, д. 87, г. Самара, 443099; m.yu.samara@mail.ru

Статья получена: 10.12.2018 Статья принята к печати: 29.03.2018 Опубликована онлайн: 12.04.2019

DOI: 10.24075 /vrgmu.2019.024

Harmonious physical development is a critical indicator of a child's health [1, 2]. Unfortunately, over $25 \%$ of schoolage children and adolescents cannot boast physical fitness [3-5], and the proportion of obese and overweight children is alarmingly high [1, 3, 6-9]. This situation is largely attributed to a contemporary lifestyle and diet that would ideally promote normal growth and development, protect against diseases and help children to adapt to the environment $[10,11]$.

Unbalanced diet and unhealthy eating habits in the critical periods of child development delay growth and may promote disease [12-14]. In recent years, the incidence of obesity in the Samara region has been stably high, reaching 54.1 cases 
per 10,000 children in 2016 . These figures are well above the average rate of 36.7 reported in the Russian Federation [15].

This dictates the need for instilling healthy lifestyle and eating habits in children. Summer may be a good time for taking measures, as many children spend their holidays in summer camps. The camps are expected to provide a wide range of activities, as well as improve a child's health. Nutrition is a crucial factor that affects the overall health, growth and development, contributing to the efficacy of health programs [16].

Advances in modern science have been instrumental in elaborating the efficacy criteria for summer camp healthcare. The guidelines on the Methods for the assessment of the efficacy of health initiatives in health resorts for children (2.4.4.012718; adopted instead of 2.4.4.0011-10), recommend using a grading scale for measuring the dynamics of height, body weight, muscular strength, and respiratory function in children during a summer camp session [17]. The expert panel of the Ministry of Healthcare of the Russian Federation on the hygiene in children and adolescents has approved a protocol ROSHUMZ-15-2014 on the Comprehensive assessment of the efficacy of health initiatives in health resorts for children (Protocol No. 4 dated May 6, 2014). The protocol proposes a method for assessing the efficacy of health programs for children based on the dynamics of height, weight, cardiovascular and respiratory function, physical fitness, and morbidity rates during a camp session. Some researchers also recommend using a cardiac exercise test [18] and tests of physical [19] and mental activity [20].

We believe that such protocols should also focus on the assessment of a child's nutritional status and the analysis of its dynamics during a summer camp session. This can help to reduce the incidence of nutrition-related diseases [21].

The methods proposed earlier are intended to analyze changes to anthropometric parameters in children with a variety of physical statuses. Recently, other approaches have been introduced, involving the use of diagnostic equipment for the assessment of a child's nutritional status [21, 22], including bioelectrical impedance analysis (BIA). However, the feasibility of BIA for such tasks still needs to be investigated.

The objective of this study was to provide a rationale for the use of bioimpedance analysis and anthropometric measurements as efficacy criteria for summer camp healthcare.

\section{METHODS}

The study was conducted in 346 children and teenagers (125 boys and 221 girls) aged 8 to 15 years from 3 summer camps located in the Samara region. The camps were selected from those recreational organizations whose directors agreed to cooperate. More than one camp was included in the study to ensure the probability of encountering different patterns of changes to the anthropometric and bioimpedance parameters. Each camp had playgrounds, sports facilities and dining halls. Specialized sports camps were not included in the study. The daily schedules were standard. The study enrolled the residents of the Samara region whose medical histories placed them into health groups I or II. Children who had chronic conditions or pronounced peripheral edemas, were undergoing medication therapy at the time of the study, permanently resided outside of the Samara region, or whose parents refused to give their consent to participate were excluded.

Measurements were performed twice: on the first and second days upon arrival to the camp, and two days before leaving for home. A camp session lasted 21 days. Anthropometric measurements were taken following a standard unified method [23]: height was measured using an anthropometer
(Kafa; Russia) with a $0.5 \mathrm{~cm}$ precision; body weight was measured on the electronic medical scales EMS-150-Massa-K (Massa-K; Russia) with a $60 \mathrm{~g}$ precision. The children's physical development was assessed using a modified regression scale for the Samara region [24]. Body composition was estimated on the ABC-01 analyzer (Medass; Russia) operated at $50 \mathrm{kHz}$ frequency. A standard tetrapolar method was applied; it is based on 4 electrodes placed over the hand and ankle of a child lying in the supine position. During the procedure, the angle between the right shoulder and the vertical body axis was $45^{\circ}$; the right forearm was parallel to the vertical body axis; the feet were positioned shoulder width apart. Bioimpedance measurements were taken in the morning before meal or 2.5-3 hours after meal. No vigorous physical activity or physiotherapy preceded the procedure. The following parameters were estimated: total fat mass (FM), skeletal muscle mass (SMM), and the basal metabolic rate (BMR) $[25,26]$. The obtained data were saved in Microsoft Excel 2010 (Microsoft; USA) and later processed in Statistica ver. 13.1 (StatSoft Inc.; USA). Body weight dynamics during a camp session were analyzed using the Wilcoxon test for paired samples. Changes in the total proportion of children with normal physical development (NPD), body weight deficit (BWD) and excess body weight (EBW) were analyzed using McNemar's chi-squared test. Between the camps, the dynamics were compared using Pearson's chi-squared test. Differences ( $\mathrm{M} \pm m$, where $\mathrm{M}$ is an arithmetic mean, $m$ is an arithmetic mean error) were considered significant at $p<0,05$.

\section{RESULTS}

Changes in the physical development during a camp session were analyzed and compared between children from 3 different camps. Data on camp 1 are shown in Table 1.

In camp 1, 62 children with NPD (47.7\%), 19 children with BWD (14.6\%) and 31 children with EBW (23.8\%) retained their physical status. A positive trend was observed in 8 children with BWD (6.2\%) and 5 children with EBW (3.8\%), whose physical development could be described as normal by the end of the session. Negative dynamics were observed in 4 children (3.1\%): although their physical health was normal when they arrived at the camp, they lost weight and developed BWD during their stay. One more child (0.8\%) was physically fit upon arrival, but later gained weight and thus joined the EBW group. The general trend in weight change was nevertheless insignificant $(p=0.415)$

The analysis of changes in the proportion of children with NPD, BWD and EBW in camp 1 did not reveal any significant differences inside those groups (Table 2).

In camp 2, 56 children with NPD (48.7\%), 16 children with BWD (13.9\%) and 31 children with EBW (27\%) retained their health status (Table 3).

A positive change was observed in 5 children with BWD (4.3\%) and 2 children with EBW (1.7\%), whose physical development was characterized as normal at the end of their stay at the camp. Three children (2.6\%) had developed BWD and 2 children (1.7\%) had gained weight, thus moving to the EBW group by the end of the camp session (Table 4). Similarly to camp 1, the overall body weight dynamics were insignificant $(p=0.585)$.

Weight trends in each separate health group (NPD, BWD, EBW) were also insignificant (Table 4).

In camp 3, 62 children with NPD (61.4\%), 13 children with BWD (12.9\%) and 6 children with EBW (5.9\%) retained their health status. Positive changes were observed in 6 children with BWD (5.9\%) and 5 children with EBW (5.0\%), who had 
moved into the NPD group. Negative dynamics were observed in 9 children who had developed body mass deficit by the end of their stay. In camp 3, the overall weight dynamics were reliable $(p=0.025)$ (Table 5).

There were more children in camp 3 who had lost weight during their stay than those who had gained it $(p=0.025)$. Of 14 children (12.2\%) who had lost weight, 9 had BWD at the end of the camp session and 5 had moved into the NPD group. Six children with initial BWD had gained weight and moved into the NPD group by the end of their stay. Importantly, weight loss during a camp session can be regarded as a positive health effect only for initially overweight children. For children with NPD and BWD such changes are not beneficial.

We analyzed the dynamics of body weight in children with different physical statuses during their stay at a summer camp
(Table 6). For children who were initially fit or overweight, the changes were statistically insignificant. For example, in camp 1 the children with NPD weighed $47.05 \pm 1.1 \mathrm{~kg}$ upon arrival and $47.34 \pm 1.12 \mathrm{~kg}(p=0.347)$ before leaving for home. At the same time, the children with weight deficit demonstrated a significant increase in their body weight by the end of a camp session. In camp 2, such children weighed $39.78 \pm 1.48 \mathrm{~kg}$ upon arrival and $41.37 \pm 1.66 \mathrm{~kg}(p=0.002)$ at the end of the camp session.

Bioimpedance analysis is expected to confirm such positive body weight dynamics. During their stay at camp, children are supposed to receive a balanced diet and enough physical exercise, which will be reflected in their bioimpedance results. Fat mass will decrease, whereas skeletal muscle mass and the basal metabolism rate will grow. In camps 1 and 2 , the average

Table 1. Analysis of overall body weight dynamics in camp 1

\begin{tabular}{|c|c|c|c|c|c|}
\hline \multirow{2}{*}{\multicolumn{2}{|c|}{ Beginning of session }} & \multicolumn{3}{|c|}{ End of session } & \multirow{3}{*}{$\begin{array}{c}\text { Total } \\
67\end{array}$} \\
\hline & & \multirow{2}{*}{$\begin{array}{c}\text { NPD } \\
62 \\
\end{array}$} & \multirow{2}{*}{$\frac{\text { BWD }}{4}$} & \multirow{2}{*}{$\frac{\text { EBW }}{1}$} & \\
\hline NPR & Абс. & & & & \\
\hline 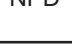 & $\%$ & 47.7 & 3.1 & 0.8 & 51.5 \\
\hline \multirow{2}{*}{ BWD } & Абс. & 8 & 19 & 0 & 27 \\
\hline & $\%$ & 6.2 & 14.6 & 0 & 20.8 \\
\hline \multirow{2}{*}{ EBW } & Абс. & 5 & 0 & 31 & 36 \\
\hline & $\%$ & 3.8 & 0 & 23.8 & 27.7 \\
\hline \multirow{2}{*}{ Total } & Абс. & 75 & 23 & 32 & 130 \\
\hline & $\%$ & 57.7 & 17.7 & 24.6 & 100 \\
\hline
\end{tabular}

Table 2. Changes in the proportion of children with NPD, BWD and EBW during a camp session in camp 1

\begin{tabular}{|c|c|c|c|c|c|c|}
\hline \multirow{2}{*}{ Dynamics } & \multicolumn{2}{|c|}{ NPD } & \multicolumn{2}{|c|}{ BWD } & \multicolumn{2}{|c|}{ EBW } \\
\hline & $n$ & $\%$ & $n$ & $\%$ & $n$ & $\%$ \\
\hline Increase & 13 & 10 & 4 & 3.1 & 1 & 0.8 \\
\hline Decline & 5 & 3.8 & 8 & 6.2 & 5 & 3.8 \\
\hline No changes & 112 & 86.2 & 118 & 90.8 & 124 & 95.4 \\
\hline Total & 130 & 100 & 130 & 100 & 130 & 100 \\
\hline Statistical significance, $p$ & \multicolumn{2}{|c|}{0.096} & \multicolumn{2}{|c|}{0.388} & \multicolumn{2}{|c|}{0219} \\
\hline
\end{tabular}

Table 3. Analysis of overall body weight dynamics in camp 2

\begin{tabular}{|c|c|c|c|c|c|}
\hline \multirow{2}{*}{\multicolumn{2}{|c|}{ Beginning of session }} & \multicolumn{3}{|c|}{ End of session } & \multirow{3}{*}{$\begin{array}{c}\text { Total } \\
61\end{array}$} \\
\hline & & \multirow{2}{*}{$\frac{\text { NPD }}{56}$} & \multirow{2}{*}{$\frac{B W D}{3}$} & \multirow{2}{*}{$\frac{\text { EBW }}{2}$} & \\
\hline RPI & Abs. & & & & \\
\hline NPL & $\%$ & 48.7 & 2.6 & 1.7 & 53 \\
\hline \multirow{2}{*}{ BWD } & Abs. & 5 & 16 & 0 & 21 \\
\hline & $\%$ & 4.3 & 13.9 & 0 & 18.3 \\
\hline \multirow{2}{*}{ EBW } & Abs. & 2 & 0 & 31 & 33 \\
\hline & $\%$ & 1.7 & 0 & 27 & 28.7 \\
\hline \multirow{2}{*}{ Total } & Abs. & 63 & 19 & 33 & 115 \\
\hline & $\%$ & 54.8 & 16.5 & 28.7 & 100 \\
\hline
\end{tabular}

Table 4. Changes in the proportion of children with NPD, BWD and EBW during a camp session in camp 2

\begin{tabular}{|c|c|c|c|c|c|c|}
\hline \multirow{2}{*}{ Dynamics } & \multicolumn{2}{|c|}{ NPD } & \multicolumn{2}{|c|}{ BWD } & \multicolumn{2}{|c|}{ EBW } \\
\hline & $n$ & $\%$ & $n$ & $\%$ & $n$ & $\%$ \\
\hline Increase & 8 & 7 & 3 & 2.6 & 2 & 1.7 \\
\hline Decline & 5 & 4.3 & 6 & 5.2 & 2 & 1.7 \\
\hline No changes & 102 & 88.7 & 106 & 92.2 & 111 & 96.5 \\
\hline Total & 115 & 100 & 115 & 100 & 115 & 100 \\
\hline Statistical significance, $p$ & \multicolumn{2}{|c|}{0.581} & \multicolumn{2}{|c|}{0.508} & \multicolumn{2}{|c|}{1} \\
\hline
\end{tabular}


values of those bioimpedance parameters increased slightly, suggesting that the children had been receiving a balanced diet and sufficient physical exercise throughout their stay, but those changes were statistically insignificant. In camp 3 , both fat and skeletal muscle masses decreased significantly. This may have been due to the inadequate diet, insufficient physical activity or a poorly structured daily schedule. Insignificant changes in the metabolism rate confirm our hypothesis (Table 7).

FM, SMM and BMR were measured in each child. Based on the measurement results, 7 groups were distinguished (Table 8). Groups 1 and 3 consist of the children who received enough exercise and healthy diet. In group 2, the children were physically active, but food intake did not compensate for energy expenditures. In group 4, the children were also quite active, but their diet was too rich in calories. The children from groups 5, 6 and 7 lacked physical activity and consumed too many calories (Table 8).

The largest proportion of children who demonstrated positive changes in their body composition (groups 1-3) was observed in camps 1 and 2 (44.61\% and $44.34 \%$, respectively). At the same time, the number of children whose fat mass had increased while their skeletal mass had not was also quite high in camps 1 and 2. In camp 3, 19.8\% of children had gained FM by the end of their stay but lost SMM or retained it at the initial level. Body weight dynamics in camp 3 inferred from the anthropometric measurements are confirmed by the presence of a significant proportion of children constituting groups 1-3.

\section{DISCUSSION}

The anthropometric measurements identified children with negative body weight dynamics observed during their stay at a summer camp: the initially fit children had developed body weight deficit or gained weight by the end of the camp session. This is an alarming trend, especially because it was observed in all three studied camps. In camp 3, body weight dynamics were statistically significant and were not always positive. Some physically fit children and their weight-deficient peers

Table 5. Analysis of overall body weight dynamics in camp 3

\begin{tabular}{|c|c|c|c|c|c|}
\hline \multirow{2}{*}{\multicolumn{2}{|c|}{ Beginning of session }} & \multicolumn{3}{|c|}{ End of session } & \multirow{3}{*}{$\begin{array}{c}\text { Total } \\
71\end{array}$} \\
\hline & & \multirow{2}{*}{$\frac{\text { NPD }}{62}$} & \multirow{2}{*}{$\frac{\text { BWD }}{9}$} & \multirow{2}{*}{$\frac{\text { EBW }}{0}$} & \\
\hline & Abs. & & & & \\
\hline INTD & $\%$ & 61.4 & 8.9 & 0 & 70.3 \\
\hline \multirow{2}{*}{ BWD } & Abs. & 6 & 13 & 0 & 19 \\
\hline & $\%$ & 5.9 & 12.9 & 0 & 18.8 \\
\hline \multirow{2}{*}{ EBW } & Abs. & 5 & 0 & 6 & 11 \\
\hline & $\%$ & 5 & 0 & 5.9 & 10.9 \\
\hline \multirow{2}{*}{ Total } & Abs. & 73 & 22 & 6 & 101 \\
\hline & $\%$ & 72.3 & 21.8 & 5.9 & 100 \\
\hline
\end{tabular}

Table 6. A summary table of children's body weight dynamics during a camp session in camps 1-3

\begin{tabular}{|c|c|c|c|c|c|c|c|c|c|c|}
\hline \multirow{2}{*}{ Camp } & \multirow{2}{*}{ Upon arrival } & \multicolumn{3}{|c|}{ Beginning of session } & \multicolumn{3}{|c|}{ End of session } & \multicolumn{2}{|c|}{ Difference $^{4}$} & \multirow{2}{*}{$p^{6}$} \\
\hline & & $M^{1}$ & $\mathrm{SD}^{2}$ & $m^{3}$ & M & SD & $m$ & M & $\mathrm{SE}^{5}$ & \\
\hline \multirow{3}{*}{ Camp 1} & NPD & 47.05 & 9.03 & 1.1 & 47.34 & 9.16 & 1.12 & 0.29 & 0.3 & 0.347 \\
\hline & BWD & 40.49 & 6.64 & 1.28 & 41.56 & 7.72 & 1.49 & 1.07 & 0.4 & 0.014 \\
\hline & EBW & 61.92 & 10.3 & 1.72 & 62.59 & 10.5 & 1.75 & 0.67 & 0.55 & 0.228 \\
\hline \multirow{3}{*}{ Camp 2} & NPD & 47.47 & 8.26 & 1.06 & 47.33 & 8.67 & 1.11 & -0.14 & 0.29 & 0.627 \\
\hline & BWD & 39.78 & 6.77 & 1.48 & 41.37 & 7.63 & 1.66 & 1.6 & 0.46 & 0.002 \\
\hline & EBW & 61.16 & 10.18 & 1.77 & 61.51 & 10.83 & 1.89 & 0.35 & 0.46 & 0.458 \\
\hline \multirow{3}{*}{ Camp 3} & NPD & 42.94 & 7.02 & 0.83 & 43.14 & 6.9 & 0.82 & 0.2 & 0.32 & 0.543 \\
\hline & BWD & 35.73 & 5.12 & 1.17 & 37.28 & 5.69 & 1.31 & 1.55 & 0.36 & $<0.001$ \\
\hline & EBW & 57.66 & 12.21 & 3.68 & 57.07 & 12.85 & 3.87 & -0.59 & 0.9 & 0.524 \\
\hline
\end{tabular}

Table 7. Bioimpedance parameters in children from camps 1-3

\begin{tabular}{|c|c|c|c|c|c|c|c|c|}
\hline \multirow{2}{*}{ Camp } & \multirow{2}{*}{ BIA parameter } & \multicolumn{2}{|c|}{ Beginning of session } & \multicolumn{2}{|c|}{ End of session } & \multicolumn{2}{|c|}{ Difference $^{4}$} & \multirow{2}{*}{$p^{6}$} \\
\hline & & $\mathrm{M}^{1} \pm m^{2}$ & $\mathrm{P}_{25-75^{3}}$ & $\mathrm{M} \pm m$ & $P_{25-75}$ & M & $\mathrm{SE}^{5}$ & \\
\hline \multirow{3}{*}{ Camp 1} & FM (kg) & $10.89 \pm 0.44$ & $7.7-13.9$ & $11.29 \pm 0.49$ & $7.3-14.3$ & 0.4 & 0.29 & 0.473 \\
\hline & SMM (kg) & $21.23 \pm 0.46$ & $17.5-25.1$ & $21.35 \pm 0.45$ & $18-25.1$ & 0.12 & 0.4 & 0.687 \\
\hline & $\operatorname{BMR}\left(\mathrm{kcal} / \mathrm{m}^{2}\right)$ & $857.04 \pm 4.98$ & $824-888$ & $865.27 \pm 5.38$ & $835-894$ & 8.23 & 0.65 & 0.262 \\
\hline \multirow{3}{*}{ Camp 2} & FM (kg) & $12.32 \pm 0.56$ & $8.1-16.5$ & $13.09 \pm 0.38$ & $8.3-17.9$ & 0.77 & 0.35 & 0.198 \\
\hline & SMM (kg) & $20.45 \pm 0.34$ & $16.6-24.3$ & $20.84 \pm 0.56$ & $17.2-24.5$ & 0.39 & 0.46 & 0.478 \\
\hline & $\operatorname{BMR}\left(\mathrm{kcal} / \mathrm{m}^{2}\right)$ & $832.54 \pm 5.34$ & $798-867$ & $846.01 \pm 4.78$ & $813-879$ & 13.47 & 0.58 & 0.061 \\
\hline \multirow{3}{*}{ Camp 3} & $\mathrm{FM}(\mathrm{kg})$ & $12.35 \pm 0.55$ & $8.7-15.9$ & $10.89 \pm 0.44$ & $7.3-14.3$ & -1.46 & 0.46 & 0.039 \\
\hline & SMM (kg) & $23.43 \pm 0.57$ & $19.3-27.5$ & $21.81 \pm 0.55$ & $18.5-25.3$ & -1.62 & 0.42 & 0.041 \\
\hline & $\operatorname{BMR}\left(\mathrm{kcal} / \mathrm{m}^{2}\right)$ & $873.32 \pm 5.45$ & $849-897$ & $862.51 \pm 5.29$ & $836-889$ & -10.81 & 0.51 & 0.155 \\
\hline
\end{tabular}


Table 8. Dynamics of bioimpedance parameters in children from camps 1-3 during a camp session

\begin{tabular}{|c|c|c|c|c|}
\hline \multirow{2}{*}{ Group } & \multirow{2}{*}{ Dynamics } & \multicolumn{3}{|c|}{ Number of children (\%) } \\
\hline & & Camp 1 & Camp 2 & Camp 3 \\
\hline 1 & Decreasing FM, stable SMM, increasing BMR & $17(13.07)$ & 14(12.17) & $12(11.89)$ \\
\hline 2 & Decreasing FM, increasing SMM, decreasing BMR & $12(9.23)$ & $16(13.91)$ & $11(10.89)$ \\
\hline 3 & Decreasing FM, increasing SMM, increasing BMR & $29(22.31)$ & $21(18.26)$ & $17(16.83)$ \\
\hline 4 & Increasing FM, SMM, BMR & $14(10.77)$ & $14(12.17)$ & $13(12.87)$ \\
\hline 5 & Increasing FM, stable SMM, decreasing BMR & $20(15.39)$ & 17(14.79) & 19 (18.81) \\
\hline 6 & Increasing FM, decreasing SMM, decreasing BMR & 24 (18.46) & $14(12.17)$ & $20(19.8)$ \\
\hline 7 & Increasing FM, decreasing SMM, increasing BMR & $14(10.77)$ & $19(16.53)$ & $9(8.91)$ \\
\hline
\end{tabular}

gained weight, which can be regarded as a positive effect, but there was also a big proportion of children who lost weight during their stay. BIA confirms the results of the conducted anthropometric measurements. Based on the dynamics of fat mass, skeletal muscle mass and basal metabolism rates measured in each child, we can assess the quality of nutrition at camps and its impact of children's health. Weight gain that serves as a criterium of healthy physical development and therefore suggests a positive effect of a health program can also result from an increase in fat content [17, 20, 25]. If children receive a balanced diet and are provided with physical activities that match food intake, changes in the body composition will not be manifested as an increase in fat mass. Skeletal muscle mass can grow or remain stable throughout a camp session $[18,19,25]$. In our study, weight gain was accompanied by a healthy increase in skeletal muscle mass, as well as by an unhealthy increase in fat mass in many children. At the same time, weight loss during the camp session was not always associated with a drop in fat mass, but in some cases was indicative of skeletal muscle mass loss, indicating the absence of a positive effect on children's health. Anthropometric measurements and BIA conducted in camp 1 suggest that the children were provided with a balanced diet and energy intake matched energy expenditures. In camp 2, the diet was probably too rich in calories and energy intake exceeded energy expenditures. In camp 3, food intake could not compensate for energy expenditures.

\section{CONCLUSIONS}

During a summer camp session, a child's anthropometric parameters and body composition undergo certain changes that can reflect his/her nutritional status. The dynamics of the anthropometric parameters and bioelectrical impedance analysis can provide information about the diet a child receives and the physical activity he/her is provided with. Therefore, anthropometric measurements and BIA can be used as efficacy criteria for summer camp healthcare.

\section{References}

1. Baranov AA, Kuchma VR, Skoblina NA, Milushkina OYu, Bokareva NA, Yampolskaya YuA. Physical development of children and adolescents of the Russian Federation. M., 2013. 192 p.

2. Skoblina NA, Fedotov DM, Milushkina OYu, Bokareva NA, Tatarinchik AA. Characteristics of physical development of children and adolescents in Arkhangelsk and Moscow: history aspects. Vestnik Severnogo (Arkticheskogo) federal'nogo universiteta. 2016. (2): 110-22.

3. Baranov AA, Kuchma VR, Skoblina NA, Milushkina OYu, Bokareva NA The main mechanisms of morphofunctional development of children and adolescents in modern conditions. Vestnik Rossijskoj akademii medicinskih nauk. 2012; (12): 35-40.

4. Kuchma VR. Inter-sectoral collaboration in the formation of a healthy lifestyle of children and teenagers: problems and solutions. Voprosy shkol'noj i universitetskoj mediciny i zdorov'ya. 2014; (3): 4-9.

5. Zigitbaev RN, Ahmadullina GH, Povargo EA, Zulkarnaev TR. Sravnitel'naya ocenka sostoyaniya zdorov'ya shkol'nikov v usloviyah promyshlennyh gorodov respubliki Bashkortostan. Medicinskij vestnik Bashkortostana. 2017; 12 (5): 15-20.

6. Gricinskaja VL. Characteristics of physical development and nutrition of schoolchildren of urban and rural population of Krasnoyarsk region. Pediatric Nutrition. 2012; (5): 8-11.

7. Malceva EA, Chesnokova LL, Mihailova LA. Anthropometrical indicators of children of prepubertatny age of the industrial city. Sovremennye problemy nauki i obrazovanija. 2016; (6): 22.

8. Skoblina NA, Milushkina OYu, Gudinova ZhV, Bokareva NA, Gavryushin MYu, Sazonova O.V., et al. The scientific-methodical substantiation of norms of body weight and the standards for physical development of children's population. Zdorov'e naseleniya i sreda obitaniya. 2018; 9 (306): 19-22.

9. Tenfold increase in childhood and adolescent obesity in four decades: new study by Imperial College London and $\mathrm{WHO}$. Available from: http://www.who.int/mediacentre/news/releases/ 2017/increase-childhood-obesity/ru/ (Data obrashcheniya: 22.12.2018)

10. Baturin AK, Pogozheva AV, Martinchik AN, Safronova AM, Keshbyants EE, Denisova NN, et al. Study of nutrition peculiarities of the population of the European and Asian part of the Arctic zone of Russia. Problems of nutrition. 2016; 85 (2): 83.

11. Kotelnikov GP, Krjukov NN, Gridasov GN, Baturin AK, Gilmiyarova FN, Berezin II, et al. The rationale for the implementation of the principles of state policy of healthy nutrition of the population of Samara region for the period till 2020. Problems of nutrition. 2011; (2): 52-7.

12. Tapeshkina NV, Klishina MN. The organization of school in the modern conditions: problems and solutions. Sibirskij meditsinskij zhurnal (Irkutsk). 2013. 122 (7): 113-7.

13. Kon IYa, Tutelyan VA, Uglickij AK, Volkova LYu. Racional'noe pitanie rossijskih shkol'nikov: problemy i in puti preodoleniya. Zdorov'e naseleniya i sreda obitaniya. 2008; 7 (184): 4-5

14. Gorelova ZhYu, Kuchma VR, Solovyeva YuV, Letuchaya TA, PlatsKoldobenko AN, Uglov SYu. Scientific substantiation and working out of a school menu options (12 day daily rations), taking into account domestic supply. The basic principles, features and benefits. Evrazijskoe Nauchnoe Ob"edinenie. 2017; 3 (25): 71-7.

15. Samarskij statisticheskij ezhegodnik: Stat. sbornik. Samara: Samarastat, 2016. 345 s.

16. Sedova AS, Sokolova SB, Laponova ED. Dynamics of functional state of children's body in conditions of shortened shifts of stationary recreation. Voprosy shkol'noj i universitetskoj mediciny i zdorov'ya. 2016; (4): 41-7. 
17. Metodicheskie rekomendacii MR 2.4.4.0127-18 «Metodika ocenki ehffektivnosti ozdorovleniya $v$ stacionarnyh organizaciyah otdyha i ozdorovleniya detej». Utverzhdeny Glavnym gosudarstvennym sanitarnym vrachom RF 11 maya 2018 g. Available from: https:// www.garant.ru/products/ipo/prime/doc/71875014/.

18. Tanina NA. Evaluation of healthcare measures efficiency in summer out-of-town recreational and rehabilitation facilities for children. Medicinskij al'manah. 2015; 2 (37): 77-9.

19. Platonova AG, Podrigalo LV. Application of motor activity for the evaluation of the effectiveness of children's rehabilitation. Voprosy shkol'noj i universitetskoj mediciny i zdorov'ya. 2014; (3): 51-2.

20. Novikova II, Vejnih PA. Metodicheskie aspekty ocenki ehffektivnosti ozdorovleniya detej i podrostkov $v$ sovremennyh usloviyah. Vesti MANEB Omskoj oblasti. 2013; 3 (3): 30-3

21. Blinova EG, Akimova IS, Chesnokova MG, Demakova LV. The results of the analysis of the anthropometric and bioimpendancemetria studies of students of Omsk city. Sovremennye problemy nauki i obrazovanija. 2014; (3): 543 p.
22. Mok E, Letellier G, Cuisset JM, et al. Assessing change in body composition in children with Duchenne muscular dystrophy: anthropometry and bioelectrical impedance analysis versus dualenergy X-ray absorptiometry. Clin Nutr. 2010; 29 (5): 633-8.

23. Kuchma VR, Vishneveckaya TYu, Yamshchikova NL. Issledovanie fizicheskogo razvitiya detej i podrostkov v sisteme social'nogigienicheskogo monitoringa. Metodicheskie ukazaniya. Utverzhdeny zamestitelem glavnogo gosudarstvennogo sanitarnogo vracha g. Moskvy 12.07 .99 g. M., 1999. 37 p.

24. Vdovenko SA, Sazonova OV, Ponomarev VA, Mazur LI, Gavryushin MYu, Borodina LM. Ocenochnye tablicy fizicheskogo razvitiya detej i podrostkov shkol'nogo vozrasta Samarskoj oblasti. Metodicheskie rekomendacii. Samara, 2018. 46 p.

25. Nikolaev DV, Shchelykalina SP. Bioimpedance analysis of the human body composition: Lectures. M., 2016. 152 p.

26. Rudnev SG, Soboleva NP, Sterlikov SA, Nikolaev DV, Starunova OA, Chernykh SP, et al. Bioimpedance study of body composition in the Russian population. M., 2014. 493 p.

\section{Литература}

1. Баранов А. А., Кучма В. Р., Скоблина Н. А., Милушкина О. Ю., Бокарева Н. А., Ямпольская Ю. А. Физическое развитие детей и подростков Российской Федерации. М., 2013. 192 с.

2. Скоблина Н. А., Федотов Д. М., Милушкина О. Ю., Бокарева Н. А. Татаринчик А. А. Характеристика физического развития детей и подростков Архангельска и Москвы: исторические аспекты. Вестник Северного (Арктического) федерального университета. 2016; (2): 110-22.

3. Баранов А. А., Кучма В. Р., Скоблина Н. А., Милушкина О. Ю., Бокарева Н. А. Основные закономерности морфофункционального развития детей и подростков в современных условиях. Вестник Российской академии медицинских наук. 2012; (12): 35-40.

4. Кучма, В. Р. Межсекторальное взаимодействие при формировании здорового образа жизни детей подростков: проблемы и пути решения. Вопросы школьной и университетской медицины и здоровья. 2014; (3): 4-9.

5. З Зигитбаев Р. Н., Ахмадуллина Г. Х., Поварго Е. А., Зулькарнаев Т. Р. Сравнительная оценка состояния здоровья школьников в условиях промышленных городов республики Башкортостан. Медицинский вестник Башкортостана. 2017; 12 (5): 15-20.

6. Грицинская В. Л. Характеристика физического развития и питания школьников городского и сельского населения Красноярского края. Вопросы детской диетологии. 2012; (5): 8-11.

7. Мальцева Е. А., Чеснокова Л. Л., Михайлова Л. А Антропометрические показатели детей препубертатного возраста промышленного города. Современные проблемь науки и образования. 2016; (6): 22.

8. Скоблина Н. А., Милушкина О. Ю., Гудинова Ж. В., Бокарева Н. А., Гаврюшин М. Ю., Сазонова О. В. и др. Научно-методическое обоснование границ нормы массы тела, используемых при разработке нормативов физического развития детского населения. Здоровье населения и среда обитания. 2018; 9 (306): 19-22.

9. ВОЗ. Ожирение и избыточный вес. Десятикратный рост числа детей и подростков с ожирением за последние сорок лет: новое исследование Имперского колледжа в Лондоне и ВОЗ. Доступно по ссылке: http://www.who.int/mediacentre/ news/ releases/2017/increase-childhood-obesity/ru/ (дата обращения: 22.12.2018).

10. Батурин А. К., Погожева А. В., Мартинчик А. Н., Сафронова А. М., Кешабянц Э. Э., Денисова Н. Н., Кобелькова И. В. Изучение особенностей питания населения Европейской и Азиатской части арктической зоны России. Вопросы питания. 2016; 85 (2): 83.

11. Котельников Г. П., Крюков Н. Н., Гридасов Г. Н., Батурин А. К., Гильмиярова Ф. Н., Березин И. И. и др. Обоснование программы реализации основ государственной политики здорового питания населения Самарской области на период до 2020 года. Вопросы питания. 2011; (2): 52-7.

12. Тапешкина Н. В., Клишина М. Н. Организация школьного питания в современных условиях: проблемы и пути решения. Сибирский медицинский журнал (Иркутск). 2013; 122 (7): 113-7.

13. Конь И. Я., Тутельян В. А., Углицкий А. К., Волкова Л. Ю. Рациональное питание российских школьников: проблемы и их пути преодоления. Здоровье населения и среда обитания. 2008; 7 (184): 4-5

14. Горелова Ж. Ю., Кучма В. Р., Соловьева Ю. В., Летучая Т. А., Плац-Колдобенко А. Н., Углов С. Ю. Научное обоснование и разработка вариантов школьного меню (12 дневных суточных рационов) с учетом домашнего питания. Основные принципы, особенности и преимущества. Евразийское Научное Объединение. 2017; 3 (25): 71-7.

15. Самарский статистический ежегодник: Стат. сборник. Самара: Самарастат, 2016. 345 с.

16. Седова А. С., Соколова С. Б., Лапонова Е. Д. Динамика функционального состояния организма детей в условиях укороченной смены стационарной организации отдыха. Вопросы школьной и университетской медицины и здоровья. 2016; (4): 41-7.

17. Методические рекомендации МР 2.4.4.0127-18 «Методика оценки эфффективности оздоровления в стационарных организациях отдыха и оздоровления детей». Утверждены Главным государственным санитарным врачом РФ 11 мая 2018 г. Доступно по ссылке: https://www.garant.ru/products/ ipo/prime/doc/71875014/.

18. Танина Н. А. Оценка эффективности оздоровительных мероприятий в летних загородных учреждениях отдыха и оздоровления детей. Медицинский альманах. 2015; 2 (37): 77-9.

19. Платонова А. Г., Подригало Л. В. Использование двигательной активности для оценки эффективности оздоровления детей. Вопросы школьной и университетской медицины и здоровья. 2014; (3): 51-2.

20. Новикова И. И., Вейних П. А. Методические аспекть оценки эффективности оздоровления детей и подростков в современных условиях. Вести МАНЭБ в Омской области. 2013; 3 (3): 30-3.

21. Блинова Е. Г., Акимова И. С., Чеснокова М. Г., Демакова Л. В. Результаты анализа антропометрических и биоимпедансометрических исследований у студентов города Омска. Современные проблемы науки и образования. 2014; (3): 543.

22. Mok E, Letellier $\mathrm{G}$, Cuisset JM, et al., Assessing change in body composition in children with Duchenne muscular dystrophy: anthropometry and bioelectrical impedance analysis versus dualenergy X-ray absorptiometry. Clin Nutr. 2010; 29 (5): 633-8.

23. Кучма В. Р., Вишневецкая Т. Ю., Ямщикова Н. Л. Исследование физического развития детей и подростков 
в системе социально-гигиенического мониторинга Методические указания. Утверждены заместителем главного государственного санитарного врача г. Москвы 12.07.99 г. М., 1999. 37 c

24. Вдовенко С. А., Сазонова О. В., Пономарев В. А., Мазур Л. И., Гаврюшин М. Ю., Бородина Л. М. Оценочные таблицы физического развития детей и подростков школьного возраста Самарской области. Методические рекомендации Самара, 2018. 46 с.

25. Николаев Д. В., Щелыкалина С. П. Лекции по биоимпедансному анализу состава тела человека. М., 2016. 152 с.

26. Руднев С. Г., Соболева Н. П., Стерликов С. А., Николаев Д. В., Старунова О. А., Черных С. П. и др. Биоимпедансное исследование состава тела населения России. М., 2014. 493 с. 